\title{
RAZVOJNE MOŽNOSTI OBČINE LOŠKI POTOK
}

Sabina Frelih, Daniel Lebar, Primož Pipan, Jasna Pisanec*

\section{Izvleček}

Pretežno gozdnato območje občine Loški Potok je ob prehodu v tržno gospodarstvo in ob osamosvojitvi Slovenije precej prizadel propad večine industrijskih obratov. Odmaknjenost območja je še dodatno poglobila problematiko pomanjkanja delovnih mest. $V$ članku so podani nekateri predlogi za omilitev posledic negativnih procesov ter konkretni predlogi za nadaljni razvoj občine.

Ključne besede: geografija podeželja, zaraščanje kulturne pokrajine, obme jnost, obrobnost, depopulacija

\section{DEVELOPMENT POSSIBILITIES OF LOŠKI POTOK MUNICIPALITY}

\begin{abstract}
After Slovenia gained its independence, and during the period of transition to the market economy, the predominantly wooded area of the Loški Potok municipality was strongly affected by the decline of the majority of industrial plants in the region. Due to its remoteness, the area does not offer many work possibilities. The paper offers several suggestions for alleviating this situation and lists concrete proposals for further development of this municipality.
\end{abstract}

Key words: Geography of countryside, overgrowing of cultural landscape, borderland, periphery, depopulation

\footnotetext{
* Študentje geografije, Oddelek za geografijo, Filozofska fakulteta, Univerza v Ljubljani, Aškerčeva 2 , SI 1001 Ljubljana, Slovenija.
} 


\section{Uvod}

Občina Loški Potok se razprostira na skrajnem jugu Slovenije. Ustanovljena je bila 6.11.1994 s sklepom slovenskega parlamenta, medtem ko je prej to območje pripadalo občinama Ribnica (Loški Potok) in Kočevje (območje Dragarske doline). Meji na Republiko Hrvaško na jugu (reka Čabranka) in jugozahodu ter na občine Kočevje, Sodražica, Ribnica, Loška dolina in Nova vas-Bloke.

\section{Fizičnogeografske značilnosti}

Izrazita je prevlada karbonatnih kamnin (apnenec, dolomit), ki pogojuje tudi hidrografsko mrežo. Edina površinska vodotoka sta Mežnarjev potok in Malenšca, ki izvirata in ponikata v Travniški uvali. Nekarbonatna matična osnova je prisotna predvsem $v$ obliki peščenjakov in skrilavih kamnin na pobočjih doline Čabranke, kjer se pojavljajo tudi površinski vodotoki. $\mathrm{Na}$ dnu Retijske in Travniške uvale prihaja po dolgotrajnejših padavinah do poplav.

Glede na povprečne letne temperature meteoroloških postaj $v$ Sodražici $\left(7,7^{\circ} \mathrm{C}\right)$, Novi vasi na Blokah $\left(6,5^{\circ} \mathrm{C}\right)$ in Babnem Polju $\left(6,1^{\circ} \mathrm{C}\right)$ lahko sklepamo, da znaša povprečna letna temperatura okoli $7^{\circ} \mathrm{C}$. Značilni so veliki temperaturni ekstremi $z$ razponom od $-30^{\circ} \mathrm{C}$ do $+30^{\circ} \mathrm{C}$. Padavine so predvsem orografskega značaja. Glede na podatke merilne postaje $v$ naselju Trava se letna količina padavin giblje med 1700 in $1800 \mathrm{~mm}$. Nizke zimske temperature in precejšnja količin padavin pogojujeta dolgotrajno snežno odejo (v povprečju okoli $90 \mathrm{dni}$ na leto). O podnebju na tem območju veliko pove tudi rek prebivalcev Dragarske doline, da so doma tam, kjer je devet mesecev zima, ostale tri mesece pa je mraz. Izrazito temperaturno inverzna lega kmetijsko najbolj ugodnih površin na dnu uval in dolin ter pogosta slana dodatno onemogočata poljedelsko, še bolj pa sadjarsko rabo površja.

Za kmetijstvo neugodne podnebne, kamninske in s tem povezane tudi pedološke razmere (prevladujejo rendzine in rjave pokarbonatne prsti) pa so toliko bolj ugodne za rast gozda. Že tako visoko gozdnatost (kar $85 \%$ !) povečuje intenzivno zaraščanje nekdanjih travniških in pašniških površin. O intenzivnem zaraščanju z gozdom pričajo tudi naslednji podatki za k.o. Trava in Draga. 
Tabela 1: Delež pašnikov in površin pod gozdom v k.o. Trava in Draga.

Tab1.: Share of pastures and woods in band use at k. c. Trava and Draga.

\begin{tabular}{|l|c|c|c|}
\hline kultura \leto & 1890 & 1956 & 1990 \\
\hline gozd & $55,57 \%$ & $73,68 \%$ & $85,65 \%$ \\
\hline pašnik (zaraščajoče) & $20,38 \%$ & $5,96 \%$ & $6,24 \%$ \\
\hline
\end{tabular}

Vir/Source: Lipovec, 1998

Dominantna gozdna združba je dinarska združba gozda jelke, bukve in spomladanske torilnice (omphalado fagetum). Delež jelke precej upada zaradi intenzivne sečnje in manjše odpornosti. Obratno je s smreko, ki ima med aktualno vegetacijo že zelo velik delež in je še posebej prisotna na površinah $v$ zaraščanju. S sekundarnim gozdom so se najprej pričele zaraščati površine $v$ vzpetem svetu, ki so od vasi bolj oddaljene in so bile tudi najkasneje izsekane. To so bili lazi, kjer so pasli živino ali pa so travo pokosili le enkrat letno. Danes so ti lazi zaraščeni do te stopnje, da razlika med primarnim in sekundarnim gozdom ni izrazita. $V$ zadnjem času je pod velikim pritiskom zaraščanja s sekundarnim gozdom tudi samo dno Dragarske doline in obrobje uvale v Loškem Potoku. Pogoji za kmetijstvo so kljub prej omenjenim slabostim (slana, temperaturna inverzija) najbolj ugodni na dnu uvale, kjer je preperelina najbolj debela. Vendar pa tu uspevajo predvsem temperaturno manj občutljive kulturne rastline, kot je na primer krompir ali pa gre za travniške površine.

\section{Zgodovinski pregled skozi glavna zgodovinska razvojna obdobja}

Loški Potok in Dragarska dolina sta imela v rimski dobi predvsem tranzitni pomen. Nemalo avtorjev omenja rimske ceste: Dvorska vas - Lužarji - Hudi Vrh - Loški Potok - Lazec - Podpreska - Čabar oziroma pri Lazcu odcep na zahod preko Starega Kota do Prezida. Od tam je ena cesta vodila proti Čabru, druga pa v Loško dolino.

V srednjem veku (13.stol.) so Loški Potok trajno poselili prebivalci iz Loške doline, potem ko jim je že poprej služil kot planina za poletno pašo njihovih ovac. Prvotni naseljenci so za svojo živino še dodatno začeli krčiti gozd, na kar spominjajo številna imena, na primer Travnik, Mali Log, Retje in druga. Kraj je prvič uradno omenjen v kroniki leta 1666, in sicer kot podružnica cerkniške župnije in kasneje Velikih Blok, že leta 1670 pa je postal tudi 
samostojna župnija. Območje je bilo upravno razdeljeno na dve gospostvi. Šegova vas in del Srednje vasi sta spadala k Ložu, vse ostale vasi pa so pripadale k ribniški graščini.

Ljudje so se v osnovi preživljali z ovčjerejo in s poljedeljstvom, dopolnilno pa so se ukvarjali še s proizvodnjo suhe robe, ki so jo prodajali na Hrvaško in Ogrsko. V kratkem obdobju so kopali tudi železovo rudo, zaradi česar so se tod naselili Slovenci iz Bohinja. Med letoma 1840 in 1856 je v Glažuti obratovala steklarna. V začetku 19. stoletja se je $v$ ovčarstvu pojavila kriza in moški - "hrvatarji" so predvsem čez zimo hodili na sezonsko drvarjenje na Hrvaško. To je trajalo vse do druge svetovne vojne (150 let!), ko je hrvatarstvo popolnoma zamrlo.

Regija je doživela gospodarski vzpon z razmahom gozdarstva v sredini 19. stoletja. Zaradi prvotnega načrta tržaške železnice, ki je predvideval traso Ljubljana - Ig - Lužarji - Bloke - morje, je bila leta 1852 v Travniku zgrajena prva žaga na parni pogon na Kranjskem. Ta je bila eden glavnih dobaviteljev tehničnega lesa za železnico. Število zaposlenih se je zopet povečalo po dograditvi Sueškega prekopa (1869). Takrat je gradbena družba kot najbolj ustrezen les za pilotiranje kanalskega obrežja v puščavskih terenih predpisala kraško jelko, ki jo je bilo tod v izobilju.

Zaradi krize v gozdarstvu in agrarne prenaseljenosti se je v 2. polovici 19. stoletja začelo izseljevanje $v$ zahodno Evropo in Severno Ameriko. Leta 1880 že skoraj ni bilo več hiše, iz katere se vsaj eden ne bi izselil v ZDA. Skupno se je iz Loškega Potoka izselilo okoli 1000 ljudi. Kljub izseljevanju je območje leta 1910 z 2500 prebivalci doseglo svoj poselitveni vrh.

Zaradi redke poseljenosti, gozdnatosti in odmaknjenosti je bilo $v$ času druge svetovne vojne območje zelo priročno za boj. Tu so se odvijale največje vojaške operacije na slovenskem ozemlju med drugo svetovno vojno. Posledica tega so bile velike žrtve med civilisti in vojaki, ogromna materialna škoda in razseljeni ter izgnani prebivalci.

V povojnem obdobju socializma so se prebivalci zaposlovali predvsem $\mathbf{v}$ gozdarstvu, z uvajanjem policentričnega razvoja pa tudi v novonastajajočih industrijskih obratih za nižje kvalificirano delovno silo. Obrati Rika, Inlesa, BPT, Saturnus Avtoopreme so območju zagotavljali tudi do 500 delovnih mest. Kljub temu pa se je predvsem višje izobraženi kader še vedno izseljeval $v$ večje regionalne centre. 
S spremembo družbenega sistema po letu 1991 je prišlo do gospodarskega nazadovanja, ko so propadli vsi našteti obrati. Brezposelnost je znašala kar 30 \%.

Novo poglavje v razvoju območja se je začelo, ko sta se krajevni skupnosti Loški Potok in Dragarska dolina združili v novo občino. Ta se je soočila z velikim pomanjkanjem delovnih mest in intenzivno vsakodnevno migracijo na delo izven občine. Tako je v obdobju januar-junij 2000 brezposelnost znašala 15,2 \% (Slovenija 12,4 \%), bruto osnova za dohodnino na prebivalca pa je leta 1999 znašala 69,1 \% slovenskega povprečja. Z nastankom nove občine so se povečala vlaganja $v$ prometno infrastrukturo, ki je bila prej zaradi obrobnega položaja regije zanemarjena, trenutno pa poteka obnova zdravstvenega doma ter ureditev križišča in parkirišča v občinskem centru.

Prebivalci tega območja so se $v$ želji po preživetju vedno morali ukvarjati z dopolnilnimi dejavnostmi. Ker so bili domači viri preskromni, jih je potreba po zaslužku gnala ven iz domačega kraja. 


\section{Poselitev}

Konec leta 2000 je občina Loški Potok s 15 preb./km2 spadala med najredkeje poseljena območja Slovenije. Na 135 km2 v 17 naseljih (767 hišnih številk), ki so na nadmorski višini 700-900 metrov, živi 2114 prebivalcev. Prevladujejo gručasta naselja $v$ dolinah in uvalah, ki potekajo $v$ dinarski smeri. Centralno naselje je Hrib-Loški Potok, največje je Retje s 474 prebivalci. Črni Potok pri Dragi je po cesti dostopen le prek Hrvaške, Glažuta pa je opuščeno gozdarsko naselje.

Naselja imajo različne funkcije:

- oskrbna funkcija: Hrib-Loški Potok, Retje, Mali Log, Podpreska, Draga,

Travnik;

- zaposlitvena funkcija: Retje, Mali Log, Podpreska, Draga, Travnik;

- upravne funkcije: Hrib-Loški Potok, Draga.

Tabela 2: Število prebivalcev po naseljih v občini Loški Potok.

Tab. 2: Number of inhabitants by settlements in the Loški Potok municipality.

\begin{tabular}{|l|r|r|r|r|c|}
\hline Naselja & $\mathbf{1 9 6 1}$ & $\mathbf{1 9 9 1}$ & indeks 61/91 & $\mathbf{2 0 0 0}$ & Indeks 91/00 \\
\hline Črni Potok & 55 & 27 & 49.09 & 26 & 96.30 \\
\hline Draga & 123 & 114 & 92.68 & 111 & 97.37 \\
\hline Hrib - Loški Potok & 368 & 379 & 102.99 & 376 & 99.21 \\
\hline Lazec & 92 & 57 & 61.96 & 52 & 91.23 \\
\hline Mali Log & 280 & 235 & 83.93 & 224 & 95.32 \\
\hline Novi Kot & 92 & 39 & 42.39 & 50 & 128.21 \\
\hline Podplanina & 95 & 47 & 49.47 & 42 & 89.36 \\
\hline Podpreska & 161 & 139 & 86.34 & 120 & 86.33 \\
\hline Pungert & 30 & 19 & 63.33 & 20 & 105.26 \\
\hline Retje & 523 & 465 & 88.91 & 474 & 101.94 \\
\hline Sr. vas pri Dragi & 73 & 46 & 63.01 & 48 & 104.35 \\
\hline Sr. vas - Loški Potok & 87 & 82 & 94.25 & 71 & 86.59 \\
\hline Stari Kot & 49 & 19 & 38.78 & 16 & 84.21 \\
\hline Šegova vas & 178 & 138 & 77.53 & 116 & 84.06 \\
\hline Trava & 118 & 40 & 33.90 & 35 & 87.50 \\
\hline Travnik & 420 & 336 & 80.00 & 333 & 99.11 \\
\hline skupaj & $\mathbf{2 7 4 4}$ & $\mathbf{2 1 8 2}$ & $\mathbf{7 9 . 5 2}$ & $\mathbf{2 1 1 4}$ & $\mathbf{9 6 . 8 8}$ \\
\hline
\end{tabular}

Vir/Source: - Krajevni leksikon Slovenije, 1995, SURS Delovno gradivo, 2001 


\section{Prebivalstvo}

Do začetka druge svetovne vojne je število prebivalcev $v$ naseljih naraščalo, le $v$ Travi je upadalo. V Novem Kotu, Starem Kotu in Pungertu pa je število prebivalcev ostalo nespremenjeno. Med letoma 1931 in 1961 je v vseh naseljih prišlo do upada števila prebivalcev, $k$ čemur je prispevala tudi vojna in izselitev Kočevarjev. Vendar pa se je upad nadaljeval tudi v naslednjem obdobju (1961-1991). Izjema $v$ tem obdobju je bilo naselje Hrib-Loški Potok, kjer je viden rahel porast prebivalstva, kar pa je tudi razumljivo, saj je to središčno naselje tega območja in danes tudi novo nastale občine.

\section{Delovna mesta}

Največji razvojni problem obravnavane pokrajine je pomanjkanje delovnih mest. S tem je povezano izseljevanje predvsem mlajših in izobraženih prebivalcev. Zato menimo, da bi bilo $v$ prvi vrsti potrebno zagotoviti več delovnih mest $v$ sami občini. Glede na to da je lesa v izobilju, predlagamo revitalizacijo nekdaj uspešnega lesnega obrata $v$ Travniku, njegovo specializacijo in morebitno povezavo z močnejšim strateškim partnerjem $v$ panogi. Seveda pa mora občina še naprej spodbujati samostojne podjetnike in mala podjetja preko Sklada za razvoj drobnega gospodarstva.

\section{Zaraščanje kmečkih površin}

Prebivalci v glavnem niso več zaposleni na območju domače občine, ampak se na delo dnevno vozijo drugam. Zato imajo manj časa za popoldansko delo na kmetiji, kot so ga imeli pred gospodarsko krizo. Rezultat tega je obsežno opuščanje kmetijskih površin. Kjer so bili še pred petimi do desetimi leti pašniki, zdaj že prevladuje grmovje in nižja drevesa. Proces ogozdovanja je dobro viden že z glavne ceste, še bolj pa je izrazit na pašnikih in travnikih v notranjosti. Glavna območja zaraščanja so Globoki laz (zahodno od naselja Mali Log) in celotna Dragarska dolina, kjer je gozd ponekod že dosegel cesto Podpreska - Trava. Če se bo ta trend nadaljeval, bo vse, kar bo ostalo od nekdanje kulturne pokrajine, le še cesta med posameznimi naselji.

Znamenita Retijska uvala z značilno pasovitostjo kmetijskih površin, katere fotografije krasijo domala vsak geografski učbenik in turistični vodnik, bi 
tako kmalu utegnila ostati le še spomin. To pa bi že resneje poseglo v identiteto kraja in njegovih prebivalcev. Širjenje gozda v Retijski uvali je neposredno pogojeno z zemljiško razdelitvijo na proge. Gozd najprej napreduje v globino na parcelo, kjer lastnik ne kosi trave. Ko jo "zavzame", se proces nadaljuje še v širino na ostale parcele. Zato predlagamo, da se Retijsko uvalo proglasi kot območje vzdrževane kulturne pokrajine.

Posledica agresivnega napredovanja gozda je tudi ta, da medvedi in ostala divjad zahajajo vedno bliže naselij, kjer onemogočajo prosto gibanje prebivalcev in povzročajo škodo na pridelkih. Tako je na primer $v$ Travi medved obral jablano le 10 metrov od hiše. Iz zaselka Pungert pa morajo zaradi nevarnosti medvedov tri šoloobvezne otroke $v$ šolo voziti s kombijem.

Problemu zaraščanja bi se zaradi pomanjkanja delovne sile in spremenjenega načina življenja lahko uspešno zoperstavili z uvajanjem ovčjereje na primer črne ovce pasme Juraschaf iz Švice, katere meso vsebuje minimalno količino holesterola in je na trgu zelo iskano. Zato bi bilo potrebno najprej prepričati domačine, saj je bila ovčjereja nekdaj sinonim za revščino. Poleg tega v celotni občini trenutno ni nikogar, ki bi se preživljal izključno s kmetijstvom. Ker so tudi kmetijska zemljišča preveč razdrobljena, predlagamo, da občina in lastniki zemljišč skupaj določijo površine za ovčjerejo in parcele na njih združijo za skupno upravljanje. Tako bi dosegli večjo ekonomijo obsega, lažje pa bi se zoperstavili tudi medvedom, ki ovčjerejcem povzročajo škodo z vdori v ograde. Občina bi lahko preko javnih del zaposlila nekaj pastirjev, ki bi skupaj z ovčarskimi psi pazili na ovce. Poleg tega, da bi zaustavili oziroma upočasnili proces zaraščanja kulturne pokrajine, bi imeli lastniki tudi dobiček, ki bi bil nedvomno večji, kakor če bi pašnike prerastel gozd.

Seveda pa morata najprej svoja stališča uskladiti država oziroma gozdarji in rejci. Znan je primer iz bližnje okolice Loškega Potoka, ko je lastnik samoiniciativno in na lastne stroške očistil 5 ha svojega zaraščajočega se pašnika, pa so mu gozdarji naprtili kazen, ker naj bi brez dovoljenja posekal gozd. Država se mora odločiti ali bo zaščitila le naravo na škodo človeka, ali pa bo varovala tudi človeka v njej. 


\section{Turizem}

Na ožjem območju občine Loški Potok ni takih naravnih ali kulturnih znamenitosti, ki bi sprožile val turističnega povpraševanja. Glavni turistični potencial območja predstavljajo samota, mir, neokrnjenost okolja, občutek, da si v pokrajini, kjer je čas obstal.

Domačini o turizmu niso razmišljali vse do začetka gospodarske krize v 90. letih, ko so začeli propadati industrijski obrati. Zaradi nepovezanosti posameznikov ( $v$ nekaterih primerih pa tudi nezadostne ponudbe) so mnogi poskusi turistične ponudbe propadli. Izjemo predstavljata izletniška Popova kmetija v Lazcu in ranč $v$ Dragi, kjer obstaja možnost turistične ježe.

V okviru turističnega društva je bil ustanovljen aktiv kmečkih žena. Ta skrbi za pestro ponudbo domačih jedi v času praznika ostrnic. Še več obiskovalcev bi lahko privabili z boljšo promocijo lokalnih znamenitosti, kot so zlata in kačja smreka, partizanska bolnica, cerkev sv. Florijana v Retijski uvali in vsakoletno tekmovanje v smučarskih skokih.

Za učinkovitejši razvoj kmečkega turizma bi bila potrebna večja povezanost lokalnega prebivalstva. To bi lahko dosegli s ponovnim odprtjem turistične pisarne, ki bi spodbujala in usmerjala domačine, ki bi si na ta način lahko ustvarili del dohodka.

\section{Obmejnost}

Takoj ko se dotaknemo razvoja turizma, trčimo tudi na soodvisnost prometnih povezav in državne meje s Hrvaško oziroma mejnih prehodov na njej. Prehodno mesto Novi Kot (Prezid) je namenjeno le dvolastnikom, njihovim sorodnikom in delovni sili ter dnevnim migrantom na delo. Uporabljati ga smejo le prebivalci naselij Novi Kot, Stari Kot in Prezid. Ostali tega prehodnega mesta ne smejo uporabljati.

Meddržavni mejni prehod Podplanina (Čabar) je namenjen le osebnemu prometu, potniški in tovorni promet pa sta prepovedana. Na cesti Trava Podplanina je zaradi številnih serpentin in širine vozišča onemogočeno srečevanje večjih vozil. Zaradi plazovitega in nestabilnega terena znaša največja uradno dovoljena teža vozil 3,5 t, kar onemogoča avtobusni promet. Poleg tega pa carinska služba deluje le na slovenski strani. 
Najbližja meddržavna mejna prehoda, ki sta namenjena tako potniškemu kot tudi tovornemu prometu (carinska služba na hrvaški in slovenski strani) sta Babno Polje (Prezid) ter Petrina (Brod na Kolpi). Loški Potok in Dragarska dolina sta tako $v$ turistično-prometnem pogledu slepa, od drugih krajev odrezana ulica in kot takšna lahko v turizmu nastopata le kot končna destinacija. $V$ takšnem stanju je tranzitni turizem neuresničljiv cilj.

Rešitev problema vidimo v asfaltiranju preostalega kilometra makadamske ceste med Novim Kotom in Prezidom. Sočasno bi bila potrebna še prekvalifikacija iz prehodnega mesta vsaj v meddržavni, če že ne mednarodni mejni prehod za potniški promet. Prav tako bi moral dobiti status meddržavnega oziroma mednarodnega mejnega prehoda za potniški promet tudi mejni prehod Podplanina.

Tako bi bil zagotovljen temelj za razvoj tranzitnega turizma. Območje bi bilo preko Novega Kota (Prezida) povezano z Loško dolino in Gorskim Kotarjem, preko Podplanine (Čabra), pa z dolino reke Kolpe. Zaradi tega v Loški Potok vsekakor ne bodo začele dreti nepregledne množice avtobusov. Tistih nekaj, ki se jih bo zaradi izboljšane dostopnosti vendarle ustavilo, pa bo pomembno prispevalo $\mathrm{k}$ spodbujanju razvoja kmečkega in gostilniškega turizma.

Glede na to, da bo tod najverjetneje že $v$ bližnji prihodnosti potekala Schengenska meja Evropske zveze, obstaja nevarnost, da bo poostren nadzor naredil mejo še bolj birokratsko in neprepustno. Po drugi strani pa je to tudi priložnost za morebitno sofinanciranje mejne infrastrukture in delovnih mest na deficitarnih mejnih prehodih.

\section{Počitniške hišice}

Izredna urejenost naselij (okolice hiš), ohranjenost okolja, čist in svež zrak, mir ter zelenje, kar kličejo po vikendih, kjer bi se homo urbanus za konec tedna spočil in nabral novih moči.

Nekatere stare, že pred več kot 20 leti zapuščene hiše obnavljajo, saj se tisti, ki so se iz njih zaradi dela preselili v Ljubljano, po upokojitvi vračajo domov. Ni malo takih, ki bi se tudi že pred upokojitvijo preselili nazaj in se vsakodnevno z avtomobilom vozili na delo v Ljubljano, vendar je vožnja, po drugače razmeroma dobri cesti, zaradi ovinkov prepočasna. 
Zaenkrat so vikendaši predvsem odseljeni domačini, ki ne gradijo novih stavb, ampak le obnavljajo stare. Ni pa izključena možnost, da bodo območje kmalu odkrili tudi drugi. V tem primeru menimo, da je treba najprej uporabiti obstoječi stavbni fond oziroma parcele, šele nato pa dati prednost novogradnjam. Zaradi številnih opuščenih hiš vidimo predvsem Dragarsko dolino kot možno območje počitniških bivališč.

\section{Šola kot vzdrževalka lokalne identitete}

Z možnostjo šolanja doma se otroci bolj močno navežejo na domače okolje. Občutek pripadnosti domačemu okolju šola krepi s spoznavanjem domačega okolja, med drugim tudi pri turističnem krožku. Poleg tega učiteljski kader predstavlja pomemben del višje in visoko izobraženega prebivalstva, brez katerega ni učinkovitega lokalnega razvoja.

Osnovna šola je organizirana kot samostojna popolna osnovna šola, ki ima v svoji sestavi tudi dva oddelka vzgojno-varstvene enote Loški Potok in en oddelek v Podpreski, kakor tudi podružnično šolo Podpreska z dvema kombiniranima oddelkoma. V OŠ dr. Antona Debeljaka so 204 učenci in 13 učiteljev, v Podpreski pa 14 učencev in 2 učitelja. V vrtcu v Loškem Potoku je 40 otrok s 5 vzgojiteljicami, v Podpreski pa skrbi ena vzgojiteljica za 9 otrok.

\section{Razvojna možnost: dom upokojencev}

Kot dodatek našemu razmišljanju bi radi predstavili še idejo o domu upokojencev v Dragarski dolini. V novem nadstandardnem naselju apartmajskega tipa bi zagotovili prostor za največ 60 ljudi iz vse Slovenije, ki bi želeli jesen življenja aktivneje preživeti v neokrnjenem okolju in na čistem zraku. Dom bi za lokalne kmete predstavljal trajnega odjemalca prehrambenih pridelkov. Sorodniki, ki bi obiskovali oskrbovance, bi bili redni gostje na kmečkih turizmih. Morda bi nekatere izmed njih to celo vzpodbudilo $k$ nakupu vikenda $v$ bližini. $Z$ domom za upokojence bi občina poleg delovnih mest pridobila še dežurnega zdravnika in morebiti celo lekarno, kar bi bistveno izboljšalo zdravstveni standard občanov. Zaradi velike razdalje do bolnišnice dom ne bi prišel v poštev za težje bolnike, ki potrebujejo intenzivnejšo zdravstveno nego. Kljub temu da se ostre zimske podnebne razmere glede privlačnosti ne morejo primerjati s tistimi v Koprskem pri- 
morju, menimo, da bi s primerno predstavitvijo pritegnili dovolj interesentov za uresničitev zamisli.

Kartogram 1: Predlog rabe prostora v občini Loški Potok.

Map 1: The proposition of land use in Loški Potok municipality. 


\section{Zaključek}

Zaradi pomanjkanja delovnih mest $v$ občini je prisotno izseljevanje, še posebej mladih in izobraženih prebivalcev, kar vpliva tudi na staranje prebivalstva. Ker je večina aktivnih prebivalcev zaposlenih $v$ industriji izven domačega kraja, se ti v bistveno manjši meri ukvarjajo $s$ kmetijstvom kot $v$ preteklosti. Ena od posledic je zaraščanje kulturne pokrajine.

Izjemna gozdnatost območja govori $v$ prid oživitvi lesnega obrata $v$ Travniku, s čimer bi zagotovili tudi nekaj novih delovnih mest. Zaraščanju nekdanjih pašnikov (pa tudi travnikov) bi se lahko zoperstavili s ponovnim uvajanjem ovčjereje. Pri tem bi najverjetneje morali povezovalno in pospeševalno vlogo prevzeti pristojni občinski organi.

Izjemnega pomena se nam zdi tudi ohranitev vzdrževane kulturne pokrajine vsaj na območju Retijske uvale.

Večja povezanost lokalnega prebivalstva, kakor tudi spodbujevalna vloga občine bi bila potrebna v primeru razvoja (kmečkega) turizma. Možnosti za razvoj turizma so dodatno omejene zaradi neustrezne kategorizacije mejnih prehodov z Republiko Hrvaško oziroma še neustrezne prometne infrastrukture ob sami meji.

Menino tudi, da bi eno od možnosti za nadaljnji razvoj lahko predstavljala izgradnja manjšega apartmajskega kompleksa $v$ Dragarski dolini, ki bi bil namenjen upokojencem iz celotne Slovenije.

\section{DEVELOPMENT POSSIBILITIES OF LOŠKI POTOK MUNICIPALITY}

\section{Summary}

Loški Potok municipality is situated in the most southern part of Slovenia and it borders on Croatia. Majority of the area is composed of carbonate rocks (limestone, dolomite) so there are only a few permanent watercourses.

At the end of the year 2000 the municipality counted 2114 inhabitants, who lived in 16 settlements. Most of them are situated between 700 and $900 \mathrm{~m}$ a.s.l. 
Due to the scarcity of employment possibilities in the area, the Loški Potok municipality is faced with emigration of especially the young and the educated. The result is the ageing of the population in the area. Since most of the active population daily commute to industrial plants elsewhere, they have less time for part-time farming as they used to have in the past. One of the results of this process is the overgrowing of the cultural landscape.

Since this area is extremely wooded, the renewal of the former sawmill in Travnik seems a logical solution, which in addition would also provide employment for some of the local inhabitants. Sheep-farming, promoted by the pertinent municipality organs, would help to restore former pastures and meadows. Of extreme importance is also the preservation of the existing cultural landscape, at least in the Retijska uvala area. A strong cooperation of the local population, supported by the municipality, would be needed to promote tourism on farms.

The possibilities for the development of tourism, however, are hindered by the insufficient categorization of border crossings with Croatia, and by the poor traffic infrastructure along the border.

One of the possibilities for further development of the area would be the construction of a smaller apartment house complex in Dragarska Dolina which could serve senior citizens from all Slovenia. 


\section{Viri in literatura}

Debeljak, J., 1972: Plenkača pesmi poje. Kulturno zgodovinska kronika Loškega potoka, KS Loški potok, Ljubljana, 165 str.

Državljani RS po občini in naselju stalnega prebivališča, starostnih skupinah in spolu 31.12.2000. SURS Delovno gradivo 2001.

Gradivo turističnega krožka OŠ dr. Antona Debeljaka, Hrib-Loški Potok.

Krajevni leksikon Slovenije. 1995. DZS, Ljubljana, 435 str.

Lipovec, B., 1998: Geografija Dragarske doline - diplomska naloga, Oddelek za geografijo, Filozofska fakulteta, Univerza v Ljubljani, Ljubljana, 96 str.

Moj sončni Loški Potok, 1995/96. Mi Mladi, Loški Potok, 24 str.

Petrič, I., 1977: Geografski razvoj Loškega potoka - diplomska naloga, Oddelek za geografijo, Filozofska fakulteta, Univerza v Ljubljani, Ljubljana, 62 str.

Regionalni vidiki razvoja Slovenije s poudarkom na finančnih rezultatih poslovanja gospodarskih družb v letu 1999, Delovni zvezki Urada za makroekonomske analize in razvoj. št. 8/letnik IX/2000.

Slovenija, pokrajine in ljudje. 1998. Mladinska knjiga, Ljubljana, 735 str.

Statistični letopis Republike Slovenije 2000 - 34 pregled po občinah.

Topografska karta 1:50.000 - list 54 Ribnica. 1996. Geodetski zavod Slovenije, Ljubljana

(http://www.geocities.com/loski_potok/slovenscina/slovensko.htm

(citirano 6.7.2001)

(http://www2.arnes.si/ osljlopo1s/

(citirano 15.7.2001)

Ustni viri:

- Anketirani prebivalci z območja Loškega Potoka

- g. Franc Vesel, Izletniška Popova kmetija v Lazcu

- g. Janko Debeljak, kmetijski pospeševalec na Občini Loški potok

- g. Jože Kumer, Koprivna 28, 2393 Črna na Koroškem

- ga. Marija Košir, učiteljica geografije na OŠ dr. Antona Debeljaka, Hrib-Loški Potok

- g. Vinko Košmrlj, referent za družbene dejavnosti na Občini Loški Potok

- Uslužbenci MNZ na mejnem prehodu Podplanina 